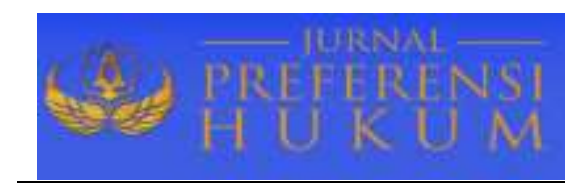

Jurnal Preferensi Hukum | ISSN: 2746-5039

Vol. 2, No. 2 -Juli 2021, Hal. 218-222| Available online at https://www.ejournal.warmadewa.ac.id/index.php/juprehum

DOI: https://doi.org/ 10.22225/jph.2.2.3291.218-222

\title{
PERLINDUNGAN HUKUM BAGI PEREMPUAN KORBAN KEKERASAN DALAM RUMAH TANGGA
}

\author{
Cokorda Istri Dharmasatyari, I Nyoman Gede Sugiartha, Ni Made Sukaryati Karma \\ Fakultas Hukum Universitas Warmadewa, Denpasar-Bali, Indonesia \\ cokistya98@gmail.com, nyomansugiharta14@gmail.com, madesukaryatikarma@gmail.com
}

\begin{abstract}
Abstrak
Penelitian ini bertujuan untuk menganalisis peran paralegal di dalam suatu Lembaga Bantuan Hukum Aliansi Perempuan Indonesia untuk Keadilan (LBH APIK), dan mengungkap hambatan-hambatan yang dihadapi dalam rangka menyelesaikan masalah di lingkup wanita serta juga untuk mempelajari secara jelas peran pendampingan pada wanita yang menjadi korban kekerasan dalam rumah tangga (KDRT). Penelitian ini menggunakan penelitian hukum empiris dengan pendekatan hukum Perundang-undangan. Sumber data yang digunakan adalah bahan hukum primer dan sekunder yang diperoleh melalui wawancara dan dibantu dengan studi kepustakaan yang berasal dari berbagai literatur. Hasil penelitian menunjukkan bahwa peran paralegal sangat penting dimulai saat korban memberikan pengaduan dan melaporkan keluhannya ke pihak LBH APIK, paralegal memberikan pertimbangan-pertimbangan mengenai proses hukum yang akan dilalui sampai pada saat akan di lakukannya persidangan dan selesainya proses hukum. Pendampingan ini dimaksudkan untuk memberikan dan meningkatkan perasaan aman, nyaman serta ketenangan secara mental maupun fisik saat korban memiliki masalah tersebut dan juga agar korban tidak kebingungan saat proses hukum tersebut berlangsung. Adapun kendala kekurangan anggota sehingga tidak efektif dan eksistensi paralegal di setiap daerahnya.
\end{abstract}

Kata Kunci: Korban, Kekerasan, Paralegal, dan Pidana

\begin{abstract}
This study aims to analyze the role of paralegals in The Indonesian Women's Alliance for Justice Legal Aid Institute and reveal the obstacles faced in solving problems in the sphere of women and also clearly study the role of mentoring for women who are victims of domestic violence. This study used empirical legal research with a statutory legal approach. Sources of data were primary and secondary legal materials obtained through interviews and assisted by literature studies from various literature. The results showed that the role of the paralegal was very important starting from the victim submitted a complaint and reported her complaint to LBH $A P I K$, the paralegal gave considerations regarding the legal process that would be passed until the trial was carried out, and the legal process was completed. This assistance was intended to provide and increase feelings of security, comfort, and peace mentally and physically when the victim has this problem, and so that the victim did not get confused as well when the legal process took place. The obstacle to the lack of members made the existence of paralegals in each region ineffective.
\end{abstract}

Keywords: Victims, Violence, Paralegal, and Criminal

\section{PENDAHULUAN}

Tujuan Negara Hukum sebagaimana termuat dalam pembukaan UUD RI 1945 yaitu untuk melindungi segenap bangsa serta seluruh tumpah air Indonesia. Maka dari itu perlunya kesadaran masyarakat untuk saling melindungi satu sama lain sehingga bisa terwujudnya kesejahteraan bermasyarakat yang adil tentram dan sejahterah sehingga tidak adanya lagi kekerasan, apalagi kekerasan dalam rumah tangga yang sekarang ini kasusnya terus meningkat. Kekerasan dalam Rumah tangga merupakan perlakuan sesorang kuhusunnya terhadap perempuan yang melanggar hak-hak perempuan dengan cara menindas dan melecehkan kehormatan wanita (Muhajarah, 2016). Lembaga Bantuan Hukum Aliansi Perempuan Indonesia untuk keadilan di tahun 2018 ada 248 kasus yang telah ditangani, Kasus yang paling banyak terjadi adalah KORT sebanyak 159 kasus, lalu ada juga diskriminasi, anak berhadapan dengan hukum $(\mathrm{ABH})$, dan juga kekerasan seksual persetubuhan. Kasus terbanyak di kota Denpasar sebanyak 154 kasus, di Kab. Gianyar, Kab. Buleleng, dan Kab. Badung. Pada tahun 2019 kasus meningkat yakni sebanyak 408 kasus telah ditangani. kasus KORT pun juga mengalami peningkatan menjadi 236 kasus yang ada, disusul juga dengan kekerasan bentuk seksual, dan juga ABH. Terbanyak melibatkan orang dewasa, lansia, dan anak-anak. Sementara menurut data yang ada pada kornpilasi BP3A Provinsi Bali 
di tahun 2018 ada 57 I kasus yang ada. Posisi terbanyak terdapat di Kota Denpasar 126, selanjutnya di susul dengan Kab. Badung sebanyak 105, Kab. Karangasem sebanyak 54 kasus, Kab. Gianyar 52 kasus, Kab. Tabanan 39 Kasus, KAb. jumlah kasusnya yaitu klungkung sebanyak 12 kasus, data yang tercatat di Polda Bali ada 28 kasus yang dilaporkan, disusul dengan data dari P2TP2A yaitu sebanyak 70 kasus. Adapun kasus yang melibatkan laki-laki yaitu sebanyak 154 orang, dan melibatkan perempuan sebanyak 417 orang. Meningkatnya jumlah kasus Kekerasan Dalam Rumah Tangga (KORT) memiliki hubungan yang erat dengan meningkatnya kesadaran hukum dari masyarakat yang mengalaminya sehingga dimuat dalam Undang-Undang Nomor 23 Tahun 2004 mengenai Penghapusan Kekerasan Dalam Rumah Tangga.

Menurut Lestari, (2017); \& Santoso, (2019) Tindakan KORT saat ini tidak hanya terjadi pada kehidupan berumah tangga saja, namun sudah menjadi urusan publik. Seluruh masyarakat baik yang terbentuk di dalam susunan kekeluargaan atau tidak di himbau untuk secara Bersama-sama mengawasi terjadinya tindak asusila ini yang biasanya sering terjadi kepada anak, istri, bisa pula pembantu rumah tangga, suami dan semua orang yang notabenenya tentu memiliki kemungkinan untuk perlakuan tidak senonoh itu. Namun hal serupa paling banyak menimpa anak dan juga istri namun tidak menuntut kemungkinan hanya itu saja bisa juga menimpa seluruh anggota didalam rumah.

Lembaga Bantuan Hukum Aliansi Perempuan Indonesia untuk Keadilan (LBH APIK) terdiri dari berbagai Dasar Hukum Paralegal ada didalam Perinenkumham Nomor I Tahun 2018 tentang paralegal dalam pemberian Bantuan Hukum yang menjadi Lembaga Bantuan Hukum Aliansi Perempuan Indonesia untuk Keadilan (LBH APIK). Dalam kasus ini peran paralegal sangatlah penting untuk dapat memberi keadilan terhadap korban yang mengalarni KORT yang berasal dari masyarakat kurang mampu. Peran pendampingan hukum ini juga telah dimuat dalam Undang-Undang Nomor 16 Tahun 2011 mengenai bantuan hukum. Dalam undang-undang tersebut dikatakan bahwa pemberi bantuan hukum dalam hal ini adalah LBH APLK berhak untuk open rekrutmen terhadap paralegal, advokat, dosen fakultas hukum ataupun mahasiswa fakultas hukum untuk ikut serta menangani kasus yang ditirnpa oleh masyarakat kita. Maka dengan hal ini peran paralegal dinyatakan telah memperoleh legitimasi hukum sehingga eksistensinya harus diakui oleh aparat penegak hukum dan instansi terkait yang akan bekerjasarna dengannya.

Penelitian terdahulu mengungkapkan bahwa Paralegal sangat penting untuk meningkatkan akses perempuan terhadap keadilan, khusunya bagi mereka yang mengalami kekerasan dalam rumah tangga (Hartanto \& Firdausy, 2014). Program pendampingan paralegal dalam memberikan perlindungan hukum terhadap korban KDRT harus dilakukan dalam bentuk tindakan preventif dan kuratif. Terbatasnya lembaga hukum akan menjadi kendala bagi orang yang membutuhkan perlindiunga hukum terutama bagi orang miskin yng mengalami kasus kekrasan dalam rumah tangga (Kalingga, 2020); \& (Fattah \&Muthmainnah, 2021). Berdasarkan kajian terdahulu penelitian ini bertujuan mengkaji Peranan dari Paralegal saat melakukan pendampingan terhadap seorang korban yang mengalarni Kekerasan dalam Rumah Tangganya dan menganalisis hambatan-hambatan yang dihadapi oleh Paralegal saat Mendampingi berbagai kasus yang khususnya Korban Kekerasan dalam Rumah Tangga.

\section{METODE PENELITIAN}

Metode penelitian yang digunakan adalah penelitian empiris, dan metode yang dipakai didalam pendekatan masalah ialah pendekatan yuridis empiris. Hal ini dikarenakan oleh berkaitannya kepada efektivitas pelaksanaan norna-norma hukum secara tertulis yang diundangkan oleh pejabat dan Lembaga yang berwenang yang dalam hal ini adalah Negara. Mengenai pelaksanaannya Undangundang Nornor 23 Tahun 2004 yang didalamnya membahas tentang cara menghapus adanya kekerasan di dalam suatu rumah tangga yang dilaksanakan oleh pengacara serta juga paralegal di bidang memberikan serta mendampingi orang yang mengalami kekerasan tersebut dalam rurnah tangganya. Bahan hukum yang digunakan adalah bahan hukum primer yaitu seperti Kitab Undang-undang Hukum Pidana (KUHP) Pasal 1 angka I UU PKDRT, Kitab Undang-Undang Hukum Acara Pidana, selanjutnya bahan hukum sekunder berpedoman pada artikel, literatur-Iiteratur, jumal hukum dan yang lain terkait dengan permasalahan. Data diperoleh dengan cara wawancara kepada pihak terkait di lembaga bantuan hukum Indonesia aliansi perempuan unruk keadilan (LBH APIK) dan terjun langsung ke lapangan sebagai data primernya, serta teknik pencatatan dan dokumentasi 


\section{HASIL DAN PEMBAHASAN}

\section{Peran Dari Pendamping (Paralegal) saat Mendampingi korban Kekerasan dalam Rumah Tangga atau KDRT}

Dalam bahasa Inggris victim memiliki seseorang atau sesuatu yang telah terluka, terbunuh atau telah menderita, atau hancur yang disebabkan baik dikarenakan oleh tindakan atau perilaku seseorang atau hal lainnya. istilah victim ini memiliki arti yang beda dengan istilah korban, hal tersebut dapat dilihat pada sebuah studi yang Namanya viktimologi, asal katanya dari victirna (bahasa latin) dan logos yang berarti ilmu pengetahuan (Lndah, 2014). Viktimologi adalah cabang ilmu yang mempelajari tentang korban sebagai victim, termasuk juga dengan hubungannya antara pelaku dan korban, serta juga kaitannya kepada interaksi antara korban dan sistem peradilan yaitu pengadilan, polisi, dan hubungan antara para pihak yang terkait didalamnya, didalamnya juga berkaitan dengan hubungan dari korban dengan kelompok sosial dan institusi (Sunggono \& Harianto, 2010). Kekerasan dalam rumah tangga adalah suatu tindakan yang dilakukan di dalam rumah tangga baik oleh isrri, suami ataupun anak, yang tentunya memiliki dampak yang buruk kepada psikis, fisik, dan juga keharmonisan di hubungan sesuai dengan yang termasuk dalam pasal 1 UU KDRT.

Lingkup tindakan kekerasan dalam keluarga adalah perbuatan yang dilakukan kepada seseorang terutamanya perempuan yang merniliki akibat timbulnya penderitaan fisik (kesengsaraan), psikologis, seksual, dan penelantaran rumah tangga yang termasuk kepada ancaman untuk melakukan suatu perbuatan melawan hukum di lingkup rumah tangga. Sebagian besar tindak KDRT pelakunya adalah seorang suami atau ayah, namun ada juga yang sebaliknya dimana pelakunya adalah orang yang tersubordinasi di dalam rumah tangga. Tidak semuanya tindak bisa ditangani dengan tuntas sebabnya yakni korban sering kali menutupi dengan berbagai alasan salah sarunya ikatan struktur agama, budaya dan belum adanya pemahaman mengenai sistem hukum yang berlaku di Indonesia. Padahal perlindungan hukurn oleh Negara dan masyarakat bertujuan untuk menciptakan rasa aman dan nyaman terhadap korban serta menindak pelaku yang bersangkutan. Orang yang mendapatkan tindakan KDRT ialah orang-orang yang sarna-sama mempunyai hubungan darah, dan anak serta bahkan jug a pembantu dalam yang tinggal disana. Pada angka 2 Undang- undang Nomor 13 Tahun 2006, tentang Perlindungan Saksi dan Korban disebutkan bahwa korban ialah seseorang yang mengalami penderitaan secara fisik, secara mental, atau mendapatkan kerugian secara ekonomi yang disebabkan oleh suaru tindak pidana (Chazawi, 2001). Undang- undang Nomor 23 Tahun 2004 sebagaimana termuat dalam pasal 3 mengenai asas dan pasal 10 hak-hak korban yang harus dipenuhi dan dipatuhi antara lain

1. Asas-asas

a) Penghormatan hak asasi manusia adalah untuk menghormati setiap hak yang dimiliki orang

b) Keadilan dan juga kesetaraan gender merupakan suatu pandangan bahwasanya semua orang atau warga Negara harus menerima suatu perlakuan yang setara dan tidak adanya diskriminasi berdasarkan dari identitas gender yang bersifat kodrati

c) Non diskriminasi ialah untuk bisa saling menghargai persamaan derajat tersebut dengan tidak mernbeda-bedakan, baik para pihak, atas dasar ras, etnis, agama, warna kulit, suku bangsa, status sosial dan status ideologi.

d) Perlindungan korban ialah dimana penegak hukum dapat memberikan rasa aman dan nyaman saat memberikan keterangan saat proses peradilan berlangsung (Bambang, 2011).

2. Hak- hak Korban

Secara khusus, korban yang mengalami tindak kekerasan dalam rumah tangganya (KDRT), memiliki hak-hak yang dapat diimplementasikan yang termuat dalam Pasal 10 Undang-undang Nomor 23 Tahun 2004 tentang Penghapusan Kekerasan dalam Rumah Tangga, yakni

1. Penanganan khusus terkait hal yang bersifat rahasia dan privasi korban

2. Adanya perlindungan hukum dari berbagai macam phak baik yang sifatnya sementara berdasarkan yang ditetapkan oleh pemerintah dan pengadilan

3. Layanan kesehatan yang sesuai dengan kebutuhan medis korban

4. Adanya bimbingan rohani

5. Dampingan dari para pekerja sosial dan bantuan-bantuan hukum sesuai dengan Perundangundangan (Waluyo Bambang, 2011 40).

Paralegal adalah seseorang yang memberikan serta melayani layanan hukum secara non litigasi yang sudah pernah diberikan pelatihan serta memiliki sertifikasi paralegal, hal ini juga terdaftar sebagai organisasi bantuan hukum yang salah satu Lembaga yang memiliki fasilitas bantuan hukum paralegal 
adalah Lembaga Bantuan Hukum Aliansi Perempuan Indonesia untuk Keadilan (LBH APIK). Upaya untuk dilakukannya pendampingan dari paralegal di Lembaga Bantuan Hukum Aliansi Perempuan Indonesia untuk Keadilan terhadap korban, dilaksanakan dari saat korban melapor ke hingga saat tuntasnya kasus tersebut. Penelitian yang didapat dan juga data terkumpul yang dilakukan pirnpinan Lembaga Bantuan Hukum Aliansi Perempuan Lndonesia untuk Keadilan diperoleh data tentang penting perlindungan dan pendampingan hukurn terhadap korban KdRT dirnulai dari kasus dilaporkan sampai selesainya kasus di peradilan. Menurut Bambang Sunggono, Aries Harianto, (2010 30-42) Terdapat beberapa strategi hukum yang dipakai oleh orang atau dalam hal ini Paralegal terhadap korban yang mengalami KDRT, yakni secara secara kualitatif dan preventif, yaitu dengan pendekatan kol abortif antara lain:

1) Pendekatan dengan pihak korban, dengan menggunakan pendekatan psikologis dan agama

2) Memberikan pelayanan kesehatan kepada pihak korban yang membutuhkan

3) Memberikan pengetahuan mengenai kecakapan hidup/life skills kepada pihak korban KDRT

4) Memberikan bantuan hukum baik di jalur litigasi maupun non litigasi kepada pihak korban

\section{Hambatan Paralegal dalam Melakukan Pendampingan dari Korban dan beserta juga Cara Penyelesaian Hambatannya.}

Dalam pelaksanaannya Undang-undang yang mengatur tentang Penghapusan Kekerasan Dalam Rurnah Tangga, seringkali menernui hambatan, baik dari penegak hukum, masyarakat, dan bahkan dari pihak korban (Widiartana, 2009). Adapun berbagai hambatan yang ditemui dari pihak korban yaitu

a. Korban ragu untuk berhubungan atau melapor ke pihak kepolisian

b. Tenggang waktu terjadinya tindak kekerasan dengan melapor ke kepolisian yang lama, sehingga tidak bisa dilakukan visum ctreyertum

c. Korban kurang mernahami bahkan tidak memahami apakah perbuatan dari pelaku merupakan tindak pidana atau pelanggaran hukum.

d. Korban malu dan bahkan tidak mau untuk melapor, karena berkaitan dengan keluarganya sendiri.

e. Korban merasa ketakutan akan keadaan rumah tangga yang semakin menderita dengan diadilinya atau dipidananya pelaku

f. Korban takut balas dendarn dari pelaku

Sedangkan harnbatan yang ditemui dari masyarakat memang masih ada yang berpendapat yang menganggap kekerasan yang dilakukan oleh seorang suami terhadap istri adalah urusan keluarga saja dan bukan termasuk kejahatan yang dapat diselesaikan melalui jalur hukum. Pendapat tersebut masih ada dan masih sangat erat dipikiran berbagai kalangan masyarakat, sehingga akan menjadi hambatan bagi penegak hukum di bidang tindak kekerasan dalam rumah tangga. Sedangkan yang dijumpai penegak hukum di lapangan yaitu

a. Dari Kepolisian yang harus menerima laporan atas kasus kekerasan dalam rumah tangga dan harus menyelidiki kebenarannya baik dari keterangan korban, saksi, dan rnasyarakat setempat. Agar segera menerangkan hak- hak korban untuk mendapatkan pelayanan pendampinga

b. perkara mengenai kekerasan yang terjadi dalam rumah tangga agar dengan ini penasehat hukum atau advokat bisa memberikan pembelaan pada saat korban memberikan keterangan di muka pengadilan

c. Dari Pengadilan dalam memberikan perlindungan terhadap korban khususnya mengenai pelaksanaan mekanisme perintah perlindungan bagi korban yang terkena dampak kekerasan dalam rumah tangga dan memberikan sanksi pidana bagi pelaku tindak kejahatan dalam rumah tangga. Pelaksanaan tugas paralegal menghadapi.

Adapun cara mencegah terjadinya kekerasan dalam rumah tangga antara lain

a. Setiap keluarga wajib untuk mengamalkan ajaran agama yang dianutnya seorang ayah/bapak harus menjadi imam bagi anak dan istri dalam mengatur urusan rumah tangga

b. Harus menerapkan dan mengembangkan komunikasi timbal batik antara suami, istri dan anak-anak

c. Seorang Istri atau lbu wajib mendidik anak sejak kecil, apabila marah jangan memukul dan berkata kasar kepada lawannya agar tidak terbiasa

d. Menyelesaikan setiap permasalahan dengan percakapan hangat antar seluruh anggota keluarga.

e. Jika terjadi pertengkaran serius, salah satu atau kedua-duanya harus meminta kepada orang yang dituakan untuk memediasi. 


\section{SIMPULAN DAN SARAN}

\section{Simpulan.}

Berdasarkan hasil pembahasan mengenai permasalahan yang dibahas dalam penelitian ini, maka dapat disimpulan bahwa Peranan dari paralegal saat melakukan pendampingan kasus yakni dari saat korban memberikan pengaduan dan melaporkan keluhannya ke pihak LBHAPIK, paralegal memberikan pertimbangan-pertimbangan mengenai proses hukum yang akan dilalui sampai pada saat akan di lakukannya persidangan dan selesainya proses hukum. Pendampingan meningkatkan perasaan aman, nyaman serta ketenangan secara mental maupun fisik saat korban memiliki masalah tersebut dan juga agar korban tidak kebingungan saat proses hukum tersebut berlangsung. Adapun kendala yang sering dialami oleh paralegal saat melakukan pendampingan hukum, misalnya dari paralegal ataupun juga pihak korbannya. Sebuah kendala bisa dinilai keefektifannya dan eksistensi paralegal di setiap daerahnya.

\section{Saran}

Terkait hasil penelitian ini, adapun yang disaramnkan oleh peneliti yaitu diharapkan kepada lembaga paralegal yang ada di Indonesia sangat diperlukan adanya penguatan kedudukan secara struktural di posisi paralegal yang berkedudukan sebagai pemberi bantuan hukum. Hal bertujuan untuk paralegal dalam melaksanakan tugasnya tidak bingung dan menyalahi aturan serta batasannya. Selain itu paralegal di Indonesia harus diadakan penambahan jumlah di setiap wilayah Indonesia agar terciptanya keadilan yang merata untuk seluruh Warga Negara Indonesia. Diaharapkan Pemerintah dan juga aparat penegak hukum, lembaga pemerintahan seharusnya diadakannya modemisasi untuk aturan hukumnya, khususnya untuk diadakannya modemisasi mengatur serta memuat tentang keberadaan paralegal. Selanjutnya peneliti menyadari masih memeiliki keterbatasan dalam melakukan penelitian ini, maka disarankan oleh peneliti selanjutnyan untuk melakukan penelitian terkait permasalahan kekerasan dalam rumah tangga.

\section{DAFTAR PUSTAKA}

Bambang, W. (2011). Viktimologi Perlindungan Korban dan Saksi. Jakarta. Sinar Grafika. Chazawi, A. (2001). Kejahatan terhadap Tubuh dan Nyawa. Jakarta. Raja Grafindo Persada.

Fattah, I., \& Muthmainnah. (2021). Peranan Para Legal Mendampingi Korban Kekerasan Perempuan dan Anak di Kota ParePare. Jurnal Pendidikan Kewarganegaraan Undiksha, 9(2), 384-395.

Hartanto, R. V. P., \& Firdausy, A. G. (2014). Paralegal dan Akses Perempuan terhadap Keadilan :Kajian Tentang Peranan Paralegal dalam Pemberdayaan Hukum Untuk Meningkatkan Akses Perempuan terhadap Keadilan. Yustisia Jurnal Hukum, 3(2), 77-87.

Kalingga, Q. R. H. (2020). Program Pendampingan (Paralegal) dalam Memberikan Perlindungan Hukum terhadap Korban Kekerasan dalam Rumah Tangga di Kecamatan Percut Sei Tuan. Jurnal Penelitian Pendidikan Sosial Humaniora, 5(1), 50-57.

Lestari, D. (2017). Kekerasan dalam Rumah Tangga Terhadap Perempuan. Jurnal Hukum \& Pembangunan, 35(3), 367.

Lndah, M. (2014). Perlindungan Korban Suatu Perspektif Viktimologi dan Kriminologi. Jakarta. Kencana.

. (2016). Kekerasan Terhadap Perempuan dalam Rumah Tangga: Perspektif Sosio-Budaya, Hukum dan Agama. Sawwa, 11(2), 127-146.

Santoso, A. B. (2019). Kekerasan dalam Rumah Tangga (KDRT) terhadap Perempuan: Perspektif Pekerjaan Sosial. Komunitas, 10(1), 39-57.

Sunggono, B., \& Harianto, A. (2010). Bantuan Hukum dan Hak Asasi Manusia. Bandung. Mandar Maju.

Widiartana. (2009). Victimologi, Perspektif Korban dalam Penanggulangan Kejahatan. 